\title{
PENGARUH GOOD CORPORATE GOVERNANCE TERHADAP NILAI PERUSAHAAN DI BURSA EFEK INDONESIA STUDI PADA SEKTOR CONSUMER GOODS PERIODE 2015-2019
}

\author{
Xva Habillah', Noviarti" ${ }^{*}$ \\ *) Dosen Tetap FEB Universiats SatyaNegara Indonesia J1.Arteri Pondok Indah No.11 Jakarta \\ Noviarti.arif@gmail.com; xvahabillah@gmail.com
}

\begin{abstract}
The purpose of this research is to find out if there is an effect of of Managerial Ownership, Institutional Ownership, Board Of Commissioners of Company Value of the sector Consumer Goods that listed at Indonesia Stock Exchange (IDX) for period 2015-2019. Population in this research is all sector Consumer Goods companies that listed in Indonesia stock Exchange (IDX) in the year 2015-2019. The sample in this research is 40 companies with porposive sampling as the sampling technique. Methods if data analysis in this research using linier regression analysis. The results of this research show that Managerial Ownership, Institutional Ownership, Board Of Commissioners partial has no effect on Company Value. The results also showed simultaneously that Managerial Ownership, Institutional Ownership, Board Of Commissioners effect on Company Value.
\end{abstract}

Keyword: Company Value (NP), Managerial Ownership (KM), Institutional Ownership (KI), Board Of Commissioners (DK).

\section{PENDAHULUAN}

Good Corporate Governance telah menarik perhatian dan perdebatan internasional karena berbagai masalah yang mengakibatkan kegagalan dan runtuhnya perusahaan. Berbagai pihak yang menyatakan bahwa salah satu penyebab runtuhnya perusahaan adalah dewan direksi dan dewan komisaris tidak memiliki pengawasan yang baik pada manajemen. Tata kelola perusahaan mulai menjadi topik menarik di indonesia semenjak 1998, salah satu penyebab terjadinya krisis di indonesia adalah lemahnya pengawasan yang dilakukan oleh dewan komisaris terhadap direksi perusahaan. Maka dari itu beberapa instansi negara yang mengatur tentang Good Corporate Governance mengeluarkan peraturan yang mengatur tentang Good Corporate Governance. Sebagai contoh, pada tahun 2006 Bank Indonesia mengeluarkan Peraturan Bank Indonesia No. 8/4/PBI/2006 tanggal 30 Januari 2006 tentang GCG bagi bank umum. Selain itu terdapat Peraturan Menteri Badan Usaha Milik Negara PER-09/MBU/2012 tanggal 06 Juli 2012 tentang penerapan tata kelola perusahaan yang baik pada BUMN, menjadi contoh peraturan yang dikeluarkan pemerintah untuk mengatur tata kelola untuk berbagai jenis-jenis peraturan yang terdapat di Indonesia.

Good Corporate Governance dapat didefinisikan sebagai proses dan struktur yang ditetapkan dalam menjalankan perusahaan dengan tujuan utama meningkatkan nilai pemegang saham dalam jangka panjang dengan tetap memperhatikan kepentingan Stakeholder yang lain. Mekanisme Corporate Governance terdiri dari mekanisme internal dan mekanisme eksternal. Mekanisme internal adalah cara dalam mengendalikan perusahaan. Seperti RUPS, komposisi dewan direksi dan dewan komisaris, pertemuan Board of Director kepemilikan manajerial, kompensasi eksekutif serta komite audit (Muryati \& Suardikha, 2014, p. 413). Sedangkan mekanisme eksternal adalah cara untuk mempengaruhi perusahaan selain dengan mekanisme internal meliputi pengendalian oleh pasar, Level Debt Financing dan Auditor Eksternal (Muryati \& Suardikha, 2014, p. 414).

Nilai perusahaan dapat diukur dengan nilai harga saham dipasar, berdasarkan terbentuknya harga saham di pasar yang merupakan refleksi dari penilaian oleh publik terhadap kinerja perusahaan secara riil. Nilai perusahaan akan naik dan menjadi tinggi bukan hanya karena mampu memaksimalkan keuntungan atau profit, melainkan juga nilai perusahaan akan naik apabila dapat memperhatikan lingkungan sosial dan masyarakat. 
Volume Penjualan Saham Menurun Tahun 2019

\begin{tabular}{|l|l|l|l|l|}
\hline \multirow{2}{*}{ Kode } & \multirow{2}{*}{ Emiten } & \multicolumn{3}{l|}{ Volume Penjualan } \\
\cline { 3 - 5 } & & $\mathbf{2 0 1 7}$ & $\mathbf{2 0 1 8}$ & $\mathbf{2 0 1 9}$ \\
\hline WIIM & Wismilak Inti Makmur Tbk. & $15 \%$ & $16 \%$ & $11 \%$ \\
\hline ALTO & Tri Bayan Tirta Tbk. & $0 \%$ & $0 \%$ & $13 \%$ \\
\hline INDF & Indofood Sukses Makmur Tbk. & $15 \%$ & $6 \%$ & $6 \%$ \\
\hline ROTI & PT Nippon Indosari Corpindo Tbk. & $1 \%$ & $2 \%$ & $0 \%$ \\
\hline ULTJ & Ultra Jaya Milk Industry Tbk. & $5 \%$ & $19 \%$ & $2 \%$ \\
\hline UNVR & Unilever Indonesia Tbk. & $3 \%$ & $3 \%$ & $4 \%$ \\
\hline CINT & PT Chitose Internasional Tbk. & $45 \%$ & $17 \%$ & $2 \%$ \\
\hline KLBF & Kalbe Farma Tbk. & $9 \%$ & $3 \%$ & $3 \%$ \\
\hline SIDO & PT Jamu dan Farmasi Sido Muncul Tbk. & $3 \%$ & $22 \%$ & $1 \%$ \\
\hline TSPC & Tempo Scan Pasific Tbk. & $2 \%$ & $1 \%$ & $1 \%$ \\
\hline
\end{tabular}

Sumber: www.idx.co.id (Data diolah Peneliti, 2020)

Dari tabel diatas terlihat adanya fenomena volume penjualan. Untuk bisa memperbaiki volume penjualan yang mengalami penurunan maka perlu diketahui faktor-faktor apa saja yang mampu mempengaruhi volume penjualan.

Volume penjualan dihitung berdasarkan target yang diasumsikan dengan realisasi yang dicapai. Volume penjualan tidak memisahkan secara tunai maupun kerdit, tetapi dihitung secara keseluruhan dari total yang dicapai. Maka volume penjualan meningkat dan biaya distribusi menurun maka tingkat pencapaian laba perusahaan meningkat. Tetapi sebaliknya bila volume penjualan menurun maka pencapaian laba perusahaan menurun.

Berdasarkan uraian diatas tentang fenomena masalah dan masih terdapatnya perbedaan hasil penelitian dari peneliti terdahulu (Research gap) maka peneliti tertarik untuk melakukan penelitian dengan mengambil judul skripsi: "Pengaruh Good Corporate Governance Terhadap Nilai Perusahaan di Bursa Efek Indonesia Studi Pada Sektor Consumer Goods Periode 20152019".

\section{METODE PENELITIAN}

Jenis penelitian yang digunakan adalah penelitian kausal (sebab-akibat). Penelitian kausal digunakan untuk mengetahui hubungan sebab-akibat dari variabel-variabel yang di teliti untuk menjawab pertanyaan penelitian. Penelitian kausal ini biasanya menggunakan metode eksperimen yaitu dengan mengendalikan variabel bebas (independent variable) yang akan mempengaruhi variabel terkait (dependent variable) pada situasi yang telah direncanakan. Variabel yang digunakan dalam penelitian ini adalah sebagai berikut:

1. Variabel independen atau bebas (X)

Variabel independen adalah variabel yang dapat mempengaruhi atau menjadi penyebab perubahan atau timbulnya variabel dependen (Y). Pada penelitian ini variabel independen yang digunakan adalah:

a. Kepemilikan manajerial

b. Kepemilikan institusional

c. Dewan komisaris

2. Variabel dependen atau terikat $(\mathrm{Y})$ 
Variabel dependen $(\mathrm{Y})$ adalah variabel yang dpengaruhi atau yang menjadi akibat karena adanya variabel independen (X). Pada penelitian ini variabel yang digunakan adalah Nilai Perusahaan.

\section{Populasi dan Sampel Penelitian}

Populasi adalah kumpulan dari semua kemungkinan orang-orang, benda-benda, dan ukuran lain yang menjadi objek yang menjadi perhatian atau kumpulan seluruh objek yang menjadi perhatian (Suharyadi dan Purwanto, 2013:7).

Sampel adalah suatu bagian dari pupulasi tertentu yang menjadi perhatian. Sampel dalam penelitian ini adalah industri sub Consumer Goods yang merupakan bagian dari populasi emiten saham yang terkumpul pada Bursa Efek Indonesia. Kiteria yang digunakan dalam penelitian ini adalah:

a. Perusahaan sub Consumer Goods yang terdaftar di Bursa Efek Indonesia dari tahun 2015-2019.

b. Perusahaan yang memenuhi data yang lengkap dan yang dibutuhkan dalam penelitian berdasarkan pada perusahaan sub Consumer Goods yang terdaftar di Bursa Efek Indonesia dari tahun 2015-2019.

\section{ANALISIS DAN HASIL PEMBAHASAN}

\section{Analisa Deskriptif}

Analisa deskrptif bertujuan untuk memberikan gambaran yang digunakan dalam penelitian ini. Data terlebih dahulu ditinjau mengenai deskriptif variabel penilaian dengan analisis statistik deskriptif. Statistik deskriptif dapat dilihat dari nilai rata-rata (mean), maksimal (maximum) dan minimal (minimum). Selengkapnya mengenai hasil statistik deskriptif penilaian dapat dilihat pada tabel sebagai berikut:

\section{Ringkasan Hasil Deskriptif}

Descriptive Statistics
\begin{tabular}{|l|l|l|l|l|}
\hline & $\mathrm{N}$ & Minimum & Maximum & Mean \\
\hline KM & 34 & 12.30 & 67.16 & 35.4181 \\
KI & 34 & .54 & .85 & .7279 \\
DK & 34 & 2.00 & 8.00 & 5.1176 \\
NP & 34 & 30.17 & 562.20 & 244.1945 \\
Valid N (listwise) & 34 & & & \\
\hline
\end{tabular}

Sumber: Output SPSS 22, 2020

Dari tabel diatas dapat terlihat nilai rata-rata, nilai minimum dan nilai maximum setiap variabel dalam penelitian ini.

Untuk variabel $\mathrm{KM}$, nilai rata-rata adalah sebesar $35,4 \%$, ini artinya total saham yang dimiliki oleh manajemen adalah sebesar $35,4 \%$ dari jumlah saham perusahaan yang dikelola. Nilai minimum sebesar $12,30 \%$, artinya sampel penelitian ini mempunyai total saham yang dimiliki manajemen sebesar $12,30 \%$ dari jumlah saham perusahaan yang dikelola. Sedangkan nilai maximum sebesar $67,16 \%$, artinya total saham yang dimiliki oleh manajemen mengalami kenaikan sebesar $67,16 \%$ dari jumlah saham perusahaan yang dikelola.

Untuk variabel KI, nilai rata-rata adalah sebesar $0,72 \%$, ini artinya jumlah saham yang dimiliki institusi yang menjadi sampel dalam penelitian ini sebesar $0,72 \%$ dari jumlah saham 
yang beredar. Nilai minimum sebesar $0,54 \%$, artinya sampel penelitian ini mempunyai jumlah saham yang dimiliki institusi sebesar $0,54 \%$ dari jumlah saham yang beredar. Sedangkan nilai maximum sebesar $0,85 \%$, artinya jumlah saham yang dimiliki institusi sebesar $0,85 \%$ dari jumlah saham yang beredar.

Untuk variabel DK, nilai rata-rata adalah sebesar 5,11\%, ini artinya anggota dewan komisaris internal maupun eksternal sebesar 5,11\% dari jumlah total anggota dewan komisaris. Nilai minimum sebesar $2,00 \%$, artinya sampel penelitian ini mempunyai anggota dewan komisaris internal maupun eksternal sebesar 2,00\% dari jumlah total anggota dewan komisaris. Sedangkan nilai maximum sebesar $8,00 \%$, artinya anggota dewan komisaris internal maupun eksternal mengalami kenaikan sebesar $8,00 \%$ dari jumlah total anggota dewan komisaris.

Nilai perusahaan, nilai rata-rata adalah sebesar $244,4 \%$, ini artinya harga saham yang menjadi sampel dalam penelitian ini sebesar $244,4 \%$ dari jumlah saham yang beredar. Nilai minimum sebesar $30,17 \%$ artinya harga saham yang menjadi sampel dalam penelitian ini sebesar 30,17\% dari jumlah saham yang beredar. Sedangkan nilai maximum sebesar 562,2\%, artinya harga saham yang menjadi sampel dalam penelitian ini mengalami kenaikan sebesar $562,2 \%$ dari jumlah saham yang beredar.

\section{Hasil Uji Normalitas Data}

Berikut ini merupakan hasil uji normalitas:

\section{Hasil Uji Normalitas}

Tests of Normality
\begin{tabular}{|l|l|l|l|}
\hline \multirow{4}{*}{} & \multicolumn{3}{|l|}{ Kolmogorov-Smirnov ${ }^{\mathrm{a}}$} \\
\cline { 2 - 4 } & Statistic & Df & Sig. \\
\hline KM & .123 & 34 & $.200^{*}$ \\
KI & .102 & 34 & $.200^{*}$ \\
DK & .129 & 34 & .165 \\
NP & .113 & 34 & $.200^{*}$ \\
\hline
\end{tabular}

*. This is a lower bound of the true significance.

a. Lilliefors Significance Correction

Sumber: Output SPSS 22, 2020

Dari hasil pengujian terlihat bahwa nilai signifikan yang diperoleh melebihi taraf signifikan yang telah ditentukan yaitu 0,05 sehingga menunjukkan bahwa data-data dalam penelitian ini terdistribusi normal.

\section{Hasil Uji F}

Hasil Uji F (Simultan) adalah untuk melihat pengaruh variabel bebas terhadap variabel terkait secara simultan. Untuk melihat hasil pengujian dapat dilihat dari tabel Anova. Berikut adalah nilai $\mathrm{F}$ hitung dan signifikan dalam penelitian ini:

\section{Hasil Uji F}

\section{ANOVA $^{\mathrm{a}}$}

\begin{tabular}{|ll|l|l|l|l|l|}
\hline Model & & Sum of Squares & Df & Mean Square & F & Sig. \\
\hline 1 & Regression & 57767.794 & 3 & 19255.931 & .846 & $.480^{\mathrm{b}}$ \\
& Residual & 682687.648 & 30 & 22756.255 & & \\
& Total & 740455.441 & 33 & & & \\
\hline
\end{tabular}

a. Dependent Variable: NP

b. Predictors: (Constant), DK, KI, KM

Sumber: Output SPSS 22, 2020 
Hasil pengujian Uji F menunjukkan nilai signifikan yang diperoleh adalah 0,480 berarti lebih kecil dari tingkat signifikan 0,05. Karena signifikan lebih kecil dari 0,05 maka Ho ditolak dan Ha diterima. Sehingga dapat disimpulkan bahwa Kepemilikan Manajerial, Kepemilikan Institusional, Dewan Komisaris secara simultan berpengaruh terhadap Nilai Perusahaan Consumer Goods.

\section{Hasil Uji T}

Uji T (Uji Parsial) digunakan untuk melihat pengaruh variabel-variabel bebas secara parsial terhadap variabel terkaitnya untuk melihat hasil pengujian dapat melihat tabel Coefficients. Berikut ini adalah hasil perhitungan nilai t hitung dan taraf signifikansinya dalam penelitian ini:

\section{Hasil Uji T}

\section{Coefficients $^{\mathrm{a}}$}

\begin{tabular}{|c|c|c|c|c|c|c|}
\hline \multirow{2}{*}{\multicolumn{2}{|c|}{ Model }} & \multicolumn{2}{|c|}{$\begin{array}{l}\text { Unstandardized } \\
\text { Coefficients }\end{array}$} & \multirow{2}{*}{$\begin{array}{l}\text { Standardized } \\
\text { Coefficients } \\
\text { Beta }\end{array}$} & \multirow[b]{2}{*}{$\mathrm{t}$} & \multirow[b]{2}{*}{ Sig. } \\
\hline & & B & Std. Error & & & \\
\hline \multirow[t]{4}{*}{1} & (Constant) & 224.317 & 262.328 & & .855 & .399 \\
\hline & KM & -.867 & 1.661 & -.095 & -.522 & .606 \\
\hline & KI & -79.138 & 341.175 & -.041 & -.232 & .818 \\
\hline & DK & 21.140 & 16.228 & .238 & 1.303 & .203 \\
\hline
\end{tabular}

a. Dependent Variable: NP

Sumber: Output SPSS 22, 2020

Hasil pengujian Uji T menunjukkan nilai signifikan untuk setiap variabel independen. Dari hasil pengujian 3 variabel independen dapat dijelaskan mengenai pengaruh secara parsial masng-masing variabel independen sebagai berikut:

a. Kepemilikan Manajerial (KM) mempunyai nilai signifikan 0,606. Nilai ini lebih besar dari tingkat signifikan 0,05 sehingga Ho diterima dan Ha ditolak. Artinya Kepemilikan Manajerial secara parsial tidak berpengaruh terhadap Nilai Perusahaan.

b. Kepemilikan Institusional (KI) mempunyai nilai signifikan 0,818. Nilai ini lebih besar dari tingkat signifikan 0,05 sehingga Ho diterima dan Ha ditolak. Artinya Kepemilikan Institusional secara parsial tidak berpengaruh terhadap Nilai Perusahaan.

c. Dewan Komisaris (DK) mempunyai nilai signifikan 0,203. Nilai ini lebih besar dari tingkat signifikan 0,05 sehingga Ho diterima dan Ha ditolak. Artinya Dewan Komisaris secara parsial tidak berpengaruh terhadap Nilai Perusahaan.

\section{Persamaan Regresi Berganda}

Berdasarkan hasil pada tabel Coefficients tersebut dapat dilihat persamaan regresi linier berganda sebagai berikut:

\section{Persamaan Regresi}

Coefficients $^{\mathrm{a}}$

\begin{tabular}{|c|c|c|c|c|c|c|}
\hline \multirow{2}{*}{\multicolumn{2}{|c|}{ Model }} & \multicolumn{2}{|c|}{ Unstandardized Coefficients } & \multirow{2}{*}{$\begin{array}{l}\text { Standardized } \\
\text { Coefficients } \\
\text { Beta }\end{array}$} & \multirow[b]{2}{*}{$\mathrm{t}$} & \multirow[b]{2}{*}{ Sig. } \\
\hline & & B & Std. Error & & & \\
\hline & (Constant) & 224.317 & 262.328 & & .855 & .399 \\
\hline & KM & -.867 & 1.661 & -.095 & -.522 & .606 \\
\hline & $\mathrm{KI}$ & -79.138 & 341.175 & -.041 & -.232 & .818 \\
\hline
\end{tabular}


\begin{tabular}{|l|l|l|l|l|l|}
\hline DK & 21.140 & 16.228 & .238 & 1.303 & .203 \\
\hline
\end{tabular}

a. Dependent Variable: NP

Sumber: Output SPSS 22, 2020

$\mathrm{Y}=224,317+-, 867 \mathrm{X} 1+-79,138 \mathrm{X} 2+21,140 \mathrm{X} 3$

Persamaan tersebut mempunyai makna:

a. $\quad$ Konstanta $=224,317$

Jika nilai variabel Kepemilikan Manajerial (X1), Kepemilikan Institusional (X2), Dewan Komisaris (X3) dianggap sama dengan nol yang artinya tidak diperhitungkan, maka Nilai Perusahaan (Y) sebesar 224,317.

b. Koefisien $\mathrm{X} 1=-, 867$

Jika nilai variabel Kepemilikan Manajerial (X1), mengalami kenaikan sebesar satu satuan, sementara Kepemilikan Institusional (X2), Dewan Komisaris (X3) dianggap tetap akan mempengaruhi penurunan, maka Nilai Perusahaan (Y) sebesar -,867.

c. Koefisien X2 $=-79,138$

Jika nilai variabel Kepemilikan Manajerial (X1), mengalami kenaikan sebesar satu satuan, sementara Kepemilikan Institusional (X2), Dewan Komisaris (X3) dianggap tetap akan mempengaruhi penurunan, maka Nilai Perusahaan (Y) sebesar -79,138.

d. Koefisien X3 $=21,140$

Jika nilai variabel Kepemilikan Manajerial (X1), mengalami kenaikan sebesar satu satuan, sementara Kepemilikan Institusional (X2), Dewan Komisaris (X3) dianggap tetap akan mempengaruhi kenaikan, maka Nilai Perusahaan (Y) sebesar 21,140.

\section{PEMBAHASAN}

1. Pengaruh Kepemilikan Manajerial, Kepemilikan Institusional, Dewan Komisaris Terhadap Nilai Perusahaan

Hasil penelitian menunjukkan kepemilikan manajerial, kepemilikan institusional, dewan komisaris secara simultan berpengaruh terhadap nilai perusahaan pada perusahaan sektor Consumer Goods. Dengan nilai signifikan uji F sebesar 0,480<0,05 maka Ho ditolak dan Ha diterima. Hasil penelitian ini menunjukkan kesamaan dengan teori.

2. Pengaruh Kepemilikan Manajerial Terhadap Nilai Perusahaan

Hipotesis pertama penelitian ini menunjukkan bahwa terdapat pengaruh kepemilikan manajerial terhadap nilai perusahaan. Hasil penelitian ini menunjukkan bahwa kepemilikan manajerial tidak berpengaruh terhadap nilai perusahaan. Hal ini dapat dilihat dari hasil pengujian statistik menunjukkan bahwa variabel kepemilikan manajerial memiliki regrasi negatif sebesar $-0,867$ dengan tingkat signifikan 0,606. Tingkat signifikan tersebut lebih besar dari 0,05 yang berarti Ha ditolak sehingga dapat dikatakan bahwa kepemilikan manajerial tidak berpengaruh secara signifikan terhadap nilai perusahaan.

3. Pengaruh Kepemilikan Institusional Terhadap Nilai Perusahaan

Hipotesis kedua penelitian ini menunjukkan bahwa terdapat pengaruh kepemilikan institusional terhadap nilai perusahaan. Hasil penelitian ini menunjukkan bahwa kepemilikan institusional tidak berpengaruh terhadap nilai perusahaan. Hal ini dapat dilihat dari hasil pengujian statistik menunjukkan bahwa variabel kepemilikan institusional memiliki regrasi sebesar $-79,13$ dengan tingkat signifikan 0,818. Tingkat signifikan tersebut lebih besar dari 0,05 yang berarti Ha ditolak sehingga dapat dikatakan bahwa kepemilikan institusional tidak berpengaruh secara signifikan terhadap nilai perusahaan.

4. Pengaruh Dewan Komisaris Terhadap Nilai Perusahaan 
Hipotesis ketiga penelitian ini menunjukkan bahwa terdapat pengaruh dewan komisaris terhadap nilai perusahaan. Hasil penelitian ini menunjukkan bahwa dewan komisaris tidak berpengaruh terhadap nilai perusahaan. Hal ini dapat dilihat dari hasil pengujian statistik menunjukkan bahwa variabel dewan komisaris memiliki regrasi sebesar 21,14 dengan tingkat signifikan 0,203 . Tingkat signifikan tersebut lebih besar dari 0,05 yang berarti $\mathrm{Ha}$ ditolak sehingga dapat dikatakan bahwa dewan komisaris tidak berpengaruh secara signifikan terhadap nilai perusahaan.

\section{KESIMPULAN DAN SARAN}

Berdasarkan hasil penelitian ini maka dapat disimpulkan sebagai berikut:

a. Kepemilikan manajerial, kepemilikan institusional, dewan komisaris berpengaruh terhadap nilai perusahaan pada perusahaan sektor Consumer Goods yang terdaftar di Bursa Efek Indonesia 2015-2019. Dengan nilai signifikan uji F sebesar 0,480<0,05 maka Ho ditolak dan Ha diterima.

b. Kepemilikan manajerial, kepemilikan institusional, dewan komisaris tidak berpengaruh terhadap nilai perusahaan pada perusahaan sektor Consumer Goods yang terdaftar di Bursa Efek Indonesia 2015-2019. Bahwa memiliki regrasi negatif sebesar -0,867 dengan tingkat signifikan 0,606 tingkat signifikan tersebut lebih besar dari 0,05 yang berarti Ha ditolak.

c. Kepemilikan institusional tidak berpengaruh terhadap nilai perusahaan pada perusahaan sektor Consumer Goods yang terdaftar di Bursa Efek Indonesia 2015-2019. Bahwa memiliki regrasi sebesar $-79,13$ dengan tingkat signifikan 0,818 tingkat signifikan tersebut lebih besar dari 0,05 yang berarti Ha ditolak.

d. Dewan komisaris tidak berpengaruh terhadap nilai perusahaan pada perusahaan sektor Consumer Goods yang terdaftar di Bursa Efek Indonesia 2015-2019. Bahwa memiliki regrasi sebesar 21,14 dengan tingkat signifikan 0,203 tingkat signifikan tersebut lebih besar dari 0,05 yang berarti Ha ditolak.

Saran yang bisa diberikan untuk penelitian ini adalah sebagai berikut:

a. Dalam penelitian ini hanya menggunakan 3 indikator yaitu kepemilikan manajerial, kepemilikan instritusional, dewan komisaris berpengaruh terhadap nilai perusahaan dari 3 variabel tersebut tidak ada yang mempengaruhi nilai perusahaan. Oleh sebab itu disarankan untuk penelitian selanjutnya perlu mengganti variabel lain yang memungkinkan mempengaruhi nilai perusahaan. Ini diperlihatkan dengan Adjusted R-Square penelitian ini menunjukkan presentase yang kecil sebesar $0,14 \%$ dari variabel perubahan nilai perusahaan yang dijelaskan oleh variabel independennya, sisanya 99,86\% dipengaruhi oleh variabel lain.

b. Penelitian ini dilakukan pada perusahaan sektor Consumer Goods yang terdaftar di Bursa Efek Indonesia, untuk itu penelitian selanjutnya dapat dikembangkan pada perusahaan sektor lain yang ada di Bursa Efek Indonesia seperti sektor keuangan.

\section{DAFTAR PUSTAKA}

Addiyah, A., dan Chariri, A. (2014). Pengaruh Good Corporate Governance Terhadap Kinerja Keuangan Perbankan. Diponegoro Of Accounting, 3(4), 1-15. 
Agoes, Sukrisno. (2011). Auditing (Pemeriksaan Akuntan) oleh Kantor Akuntan Publik. Edisi 4. Penerbit Salemba Empat.

Agustiana, Priska Wijayanti. (2013). Pengaruh Good Corporate Governance Terhadap Nilai Perusahaan. Universitas Pasundan Bandung. Skripsi.

Akhmad Riduwan, Enggar Fibria Verdana Sari. (2013). Pengaruh Corporate Governance, Kepemilikan Institusional, Kepemilikan Manajerial dan Komite Audit Terhadap Nilai Perusahaan. Jurnal Ilmu Riset dan Akuntansi. Vol 1. No 1. Januari 2013. Sekolah Tinggi Ilmu Ekonomi Indonesia (STIESIA). Surabaya.

Aldino, Raja. (2015). Pengaruh Corporate Governance Terhadap Nilai Perusahaan pada Perusahaan Manufaktur yang Terdaftar di (BEI) 2010-2012. Jom Fekom. Vol 2. No 1. Hal $1-15$.

Alfinur. (2016). "Pengaruh Mekanisme Good Corporate Governance Terhadap Nilai Perusahaan pada Perusahaan yang Listing di BEI". Jurnal Ekonomi Moderisasi. Vol 12. No 1.

Amin Widjaja Tunggal. (2012). Internal Auditing. Edisi 5. Yogyakarta: BPFE

Andri Veno. (2015). Pengaruh Good Corporate Governance Terhadap Kinerja Perusahaan Pada Perusahaan Manufaktur Go Public (Studi Empiris pada Perusahaan yang Terdaftar di BEI 2011 Sampai 2013). BENEFIT Jurnal Manajemen dan Bisnis Vol 19. Nomor 1. Hal 95112.

Annual Report dan Laporan Keuangan Perusahaan Industri Consumer Goods Periode 2015-2019, diakses pada tanggal 12 Maret 2020 dari http://www.idx.co.id

Ardanty, D. dan Sofie. (2016). "Pengaruh Mekanisme Corporate Governance Terhadap Ketepatan Waktu Pelaporan Keuangan Pada Perusahaan Manufaktur Yang Terdaftar Di Bursa Efek Indonesia". E-Jurnal Akuntansi Universitas Trisakti.

Arifani, R. (2013). Pengaruh Good Corporate Governance Terhadap Kinerja Keuangan Perusahaan. Malang: Universitas Brawijaya.

Ariyani, Ni Nyoman Trisna Dewi dan I Ketut Budiartha. (2014). Pengaruh Profitabilitas, Ukuran Perusahaan, Kompleksitas Operasi Perusahaan dan Reputasi KAP Terhadap Audit Report Lag Pada Perusahaan Manufaktur. E-Jurnal Akuntansi Universitas Udayana 8.2 (2014): 217-230.

Bernandhi, Riza. (2013). Pengaruh Kepemilikan Manajerial, Kepemilikan Institusional, Kebijakan Deviden, Leverage dan Ukuran Perusahaan Terhadap Nilai Perusahaan. Skripsi Fakultas Ekonomi dan Bisnis Universitas Diponegoro.

Dr. Riduwan (2014). Pengantar Statistika Untuk Penelitian Pendidikan Sosial, Ekonomi, Komunikasi dan Bisnis. Cetakan ke-4. Bandung. Alfabeta.

Eisenhardt, Kathleem. (1989). Agency Theory: An Assesment and Review. Academy of Manajement Review, 14. Hal 57-74.

FCGI, Peranan Dewan Komisaris dan Komite Audit dalam Pelaksanaan Corporate Governance (Tata Kelola Perusahaan) Jilid II, Jakarta: Citra Graha.

Ghozali, Imam. (2011). Aplikasi Analisis Multivariate dengan Program IBM SPSS 19 Edisi 5. Semarang: Badan Penerbit Universitas Diponegoro.

Hardikasari, Eka. (2011). Pengaruh Penerapan Corporate Governance Terhadap Kinerja Keuangan Pada Industri Perbankan Yang Terdaftar Di Bursa Efek Indonesia (BEI) Tahun 2006-2008. Semarang: Fakultas Ekonomi dan Bisnis. Universitas Diponegoro.

Haruman, Tendi. (2008). "Struktur Kepemilikan, Keputusan Keuangan dan Nilai Perusahaan". Finance and banking Journal. Vol 10. Nomor 2. Hal. 150-165. Bandung.

Ichsan. (2013). Teori Keagenan (Agency Theory), 2013 (https://bungrandhy.wordpress.com/2013/01/12/teori-keagenan-agencytheory/).

IICG : http://www.iicg.org. Diakses pada tanggal 13 Maret 2020.

Ikbal, Muhammad, Sutrisno dan Ali Djamhuri. (2011). Pengaruh Profitabilitas dan Kepemilikan Insider Terhadap Nilai Perusahaan dengan Kebijakan Utang dan Kebijakan Deviden sebagai Variabel Intervening. Simposium Nasional Akuntansi XIV. Aceh.

Iswanto, dan Raharja Maharani, N. (2015). Microcontroller Teori dan Praktek Atmega16 Dengan Bahasa C. Yogyakarta: CV Budi Utama. 
Jensen, Michael C. dan W. H. Meckling. (1976). Theory of The Firm: Managerial Behavior, Agency Cost and Ownership Structure. Journal of Financial Economics 3. Hal 305-360.

Komite Nasional Kebijakan Governance (KNKG). (2006). Pedoman umum Good Corporate Governance Indonesia. Jakarta. Diakses pada tanggal 10 April 2020.

Market rangking GCG di Asia 2019, Diakses pada tanggal 11 Maret 2020 dari http://www.new.acga.asia.org

Moniaga. Fernandes. (2013). Struktur Modal, Profitabilitas dan Struktur Biaya Terhadap Nilai Industri Keramik, Procelen, dan Kaca Periode 2007-2011. Jurnal EMBA. Vol 1. Nomor 4. ISSN 2303-1174.

Muryati, N. N. T. S. dan Suardikha, I. M. S. (2014). "Pengaruh Corporate Governance Pada Nilai Perusahaan". E-Jurnal Akuntansi Universitas Udayana. Vol 9. No 2. November. Hal 411429.

Perdana, Ramadhan Sukma dan Raharja. (2014). Analisis Pengaruh Corporate Governance Terhadap Nilai Perusahaan. Diponegoro Journal of Accounting. Semarang: Universitas Diponegoro.

Permana, Ni Putu Ayu Cyntia, (2012). Pengaruh Managerial Ownership Laverage Ratio dan Dividen Payout Ratio. Skripsi.

Tangkilisan, Hessel Nogi S. (2003). Manajemen Keuangan Bagi Analisis Kredit Perbankan Mengelola Kredit Berbasis Good Corporate Governance. Balairung. Yogyakarta.

Tsabat, Atsil. (2015). Pengaruh Tax Avoidance, Kepemilikan Institusional, Kepemilikan Manajerial, komisaris Independen, Komite Audit, dan Auditor Eksternal Terhadap Nilai Perusahaan. Skripsi. Bandung: Fakultas Ekonomi Universitas Pasundan.

Taufik, Indra Wila. dan Prijati. (2016). "Analisis Pengaruh Mekanisme Good Corporate Governance Terhadap Nilai Perusahaan”. Jurnal Ilmu dan Riset Manajemen. Vol 5. No 2 hal 1-19. ISSN: 2461-0593.

Salafudin, Muhammad Alfian. (2016). Pengaruh Good Corporate Governance Terhadap Nilai Perusahaan Consumer Goods Industry yang Terdaftar di Bursa Efek Indonesia (BEI). Sekolah Tinggi Ilmu Ekonomi Perbanas. Surabaya.

Sari, A. A Pt. Agung Mirah Purnama dan Putu Agus Ardiana. (2014). Pengaruh Board Size Terhadap Nilai Perusahaan. E-Jurnal Akuntansi Universitas Udayana 7.1 (2014) Hal:177191. Universitas Udayana. Bali.

Shleifer, A dan R.W. Vishny. (1997). A Survey of Corporate Governance. Journal of Finance. 52 (2), 737-783.

Suharyadi, Purwanto. 2013 Statistika: Untuk Ekonomi dan Keuangan Modern Edisi 2 Penerbit. Jakarta: Salemba Empat.

Sukirni, Dwi. (2012). Kepemilikan Manajerial, Kepemilikan Institusional, Kebijakan Dividen dan Kebijakan Hutang Analisis Terhadap Nilai Perusahaan (Studi Tentang Perusahaan yang Terdaftar di Bursa Efek Indonesia Tahun 2008-2010). Accounting Analysis Journal. ISSN 2252-6765.

Sutan Remy Sjahdeini. Perbankan Islam. Jakarta: PT. Pustaka Utama Grafiti. (1999). 